\title{
The Effect of English Teacher's Instructional Management Skills on Beginner Students' Achievement and Perception
}

\author{
Burhanuddin Yasin \\ Universitas Syiah Kuala, Indonesia, burhansyasin@unsyiah.ac.id \\ Faisal Mustafa \\ Universitas Syiah Kuala, Indonesia, faisal.mustafa@unsyiah.ac.id
}

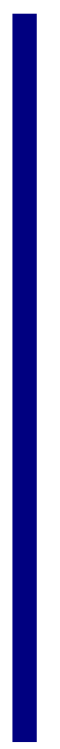

\begin{abstract}
Instructional management and instructional quality are two key factors for successfully teaching a language. This study was aimed at finding any correlation between instructional management skills and instructional quality, in addition to any correlation between instructional management skills and the achievements of the students in the relevant subject. The data for this correlational study was obtained from 30 English teachers and 531 students in the province of Aceh, Indonesia. The data was collected using two questionnaires, one for each teacher's self-reported instructional management skills, sourced from Martin and Sass (2010) and the other for their instructional quality as perceived by their students sourced from Voss, Kunter, and Baumert (2011, p. 960).The internal consistency of both questionnaires was satisfactory, viz: 0.75 and 0.70 respectively. A total number of 509 students were given a language test to test the quality of their achievements. The correlations between the variables were calculated by using Spearman's rank correlation, with a level of significance of 0.1 and 0.05 . After the data were separated based on sex and years of instruction, the results showed that only two components of instructional quality were significantly correlated to some instructional management skills. No statistical evidence was found for any correlation between the instructional management skills of the teachers with the achievements of their students.
\end{abstract}

Keywords: instructional management, instructional quality, EFL, perception, achievements

\section{INTRODUCTION}

The instructional management skills of a teacher have been claimed to be one of the most significant components in achieving success in teaching-learning a language. Sass, Lopes, Oliveira, and Martin (2016) define instructional management as the way that teachers manage their classrooms. Therefore, instructional management is also 
commonly referred to as classroom management. To assess the teacher's instructional management ability, Martin and Sass (2010) have developed an instructional management scale, which can be used by teachers to self-assess themselves. Using this scale, it is no longer necessary for some other teacher to observe a classroom because, according to a concept described by Epstein (1973), the way teachers manage the classroom is reflected through their opinion about how a classroom should be managed.

Another significant factor determining the quality of English language teaching is the teachers' pedagogical competence (Rahman, 2014). This competence covers classroom management, pace of instruction, cognitive activations, student and teacher relationships, and awareness of students' comprehension problems (Voss, Kunter, \& Baumert, 2011). Each of these components contributes to the quality of instruction in a classroom (Grossman, 2009; Kunter \& Voss, 2013; Saraswaty, 2018). In addition, there is a consensus that a teacher's instructional quality is correlated to students having a better learning experience. Therefore, instructional quality is included in the teachers' certification tests in the U.S. (Wilson \& Youngs, 2009).

Despite the significance of instructional management skills and instructional quality for a teacher, previous research provides little information on any correlation between these two variables. In addition, any correlation between the instructional management skills of a teacher and the achievements of her/his students has not been adequately studied. Therefore, this study used the self-reported instructional management skills of teachers and their students' perceptions of instructional quality plus the achievements of those students to find answers to the following two research questions:

1. In an English language classroom, will there be any significant correlation between the instructional management skill of a teacher and how his/her students perceive the quality and competence of their instruction?

2. In an English language course, will there be any significant correlation between the instructional management skills of the teacher and the achievements of their students?

\section{REVIEW OF LITERATURE}

\section{Instructional Management}

Instructional management has long been recognized as the most important part of education management (Ghofur, Rupawandi BR, \& Ahmad, 2017). Kurdi and Aziz (2006) state that the word "instruction" has a broader understanding than the word "teaching". The word "teaching" exists in the context of teachers and students in a formal class (Brown, 2000), while "instructional" can include teaching and learning activities for which the teacher is not physically present (Callahan, 2006). Therefore, in any instructional activity, emphasis is placed on the learning process, instead of being focused on the teacher. Thus, planned efforts in manipulating learning resources need to be made so that the learning process occurs in the students. The learning process contains two activities, namely teaching and learning. Learning is defined as a change in action through the activity of organizing or regulating the environment as well as possible so as to create opportunities for students to participate in an effective teaching and learning process (Pritchard, 2009). In this case, instruction is used to facilitate 
learning. Thus, instructional management is defined as the effort to manage the learning environment intentionally so that someone learns to behave in certain conditions (Mulyasa, 2002). It includes the processes of planning, implementation, and assessment (Gunawan, 2014, p. 4). It comprises learning management, classroom management, and student management (Raganas \& Collado, 2015). In the learning process, the teacher acts as a manager who manages all the processes of the learning activities (McLeod, Fisher, \& Hoover). Apparently, instructional management skills tend to improve after several years of experience as a teacher (Unal \& Unal, 2012).

\section{Student Perception of Teachers' Instructional Quality}

Pedagogical competence is defined as "the ability to understand the learners, to design curriculum or syllabus, and to actualize the learners into their various potentials" (Puspitasari, Anugerahwati, \& Rachmajanti, 2016). In Indonesia, the Decree of the Ministry of Education and Culture of Indonesia No. 16 of 2007 states that some components of pedagogical competence determine instructional quality, i.e. complete knowledge of each student's characteristics, teaching principles and methods, curriculum and lesson planning, ability to use technology in teaching, ability to communicate with students, ability to assess and to use results for teaching improvement. These components are very closely in line with the pedagogical knowledge needed of teachers as presented in Voss and Kunter (2013).

The pedagogical competence of a teacher can be assessed quantitatively using an appropriate test (König, Blömeke, Paine, Schmidt, \& Hsieh, 2011; Voss \& Kunter, 2013). This procedure of assessment has been used in the United States as a recruitment and certification instrument called Praxis, designed by the Educational Testing Service (Goe, Bell, \& Little, 2008). A more complex procedure of measurement has also been described by Puspitasari et al. (2016). There they used several instruments to measure pedagogical competence, including documentation, questionnaires for teachers and their students, interviews, and classroom observations.

Instructional quality, where pedagogical competence is reflected, can be assessed using student ratings of instructional quality, this has been validated by Voss et al. (2011): They have stated that ratings of the instructional quality of a teacher by his/her student can also be used to measure that teacher's pedagogical competence. In their rating scale, the components of instructional quality included were cognitive activation, pace of instruction, classroom management, student-teacher relationships, and awareness of comprehension problems amongst the students.

\section{Factors Influencing the Achievements of EFL Students}

The variable of achievement by a student in language teaching is a very complex variable. The success of language teaching is very often measured based on the achievements of the students. However, there are many factors predicted to effect the achievements of a student. According to Voss and Kunter, (2013), the learning achievements of a student' is determined by "the character of the individual student". Among others, these characteristics can include learning styles, aptitude, motivation, and intelligence (Duff, 2017). 


\section{Learning style}

Learning style is one of the characteristics which differentiate one student from another in accordance with their learning phase preferences (Kolb \& Kolb, 2005). The learning styles can be categorized into at least 20 style dimensions, and many of them are important for language learning (Dörnyei \& Skehan, 2008). In terms of how a learner processes information, Reid (1995) categorized them into auditory, kinesthetic, visual, and tactile learners. Research has discovered that the learning style can be correlated to the learning outcome of a student (Cassidy \& Eachus, 2000). Learning styles can be determined by using a questionnaire, such as Lau and Gardner (2019).

\section{Language aptitude}

Language aptitude refers to the ability to learn a language, i.e. it is easier for some students to learn a language than for others (Wen, 2012). It is a strong predictor of success in learning a language (Skehan, 2012). However, according to Zafar and Meenakshi (2012), language aptitude alone does not determine the ability to learn a language, but it correlates to success in learning a language. Regarding the measurement of language aptitude, some foreign language aptitude batteries have been developed, such as the Modern Languages Aptitude Test (MLAT) (Carroll \& Sapon, 1957), the LLAMA Language Aptitude Test (Meara, 2005), and the Cognitive Ability for Novelty in Acquisition of Language - Foreign (Grigornko, Sternberg, \& Ehrman, 2000). These test batteries have been well validated for reliability in measuring language aptitude (Grigornko et al., 2000; Rogers, Meara, Barnett-Legh, Curry, \& Davie, 2017).

\section{Motivation}

Learning motivation is a favorite research topic in classroom action research because positive motivation can determine success in language learning (Dörnyei \& Skehan, 2008; Zafar \& Meenakshi, 2012). Therefore, much classroom action research has investigated how to positively motivate students to learn (Kemp, 2009; Waddington, 2018). According to McDonough (2007), the "teacher's role...is central, and difficult" in motivating students to learn. In language learning, motivation can be improved through the use of innovative teaching methods and activities that can be fun for students (Hung, 2018). With the presence of technology, there have been many attempts to maximize the use of blended learning to improve the motivation of students (Butler, Someya, \& Fukuhara, 2014).

\section{Intelligence}

Although it is practice which determine success, it is believed that intelligence plays a very significant role in shaping success in learning a language (Mercer, 2012), and it is also associated with language aptitude (Dörnyei \& Skehan, 2008). Green and Tanner (2005) described that people with different types of intelligence process information differently, and thus they can benefit for certain types of tasks in different ways. For example, learners with stronger intrapersonal intelligence learn better alone, while those with stronger interpersonal intelligence learn better in groups. To find out which type of 
intelligence is stronger for one person, we can use a non-verbal test of analytic intelligence (Gutierrez, Holladay, Clarkson, Larsen, \& Srivastava, 2019).

\section{Instruction}

Other significant factors which can affect learning achievements are the different types of language instruction delivered by teachers (Nassaji, 2017). Research studies on various types of instruction, represented by methods, strategies, models, activities, and media have been widely conducted in the field of language learning since the early period of language teaching. The selection of the type of instruction can determine the quality of instruction (Donné, Fraser, \& Bousquet, 2016). In addition, instructional management has been claimed to contribute to the learning outcomes of students. (Baumert et al., 2010). However, empirical evidence supporting this claim is lacking.

\section{Research Hypotheses}

The literature reviews cited above show that the effects of teachers' instructional management skills on instructional quality and student achievements has not yet been proven using scientific studies. These effects can be investigated using correlation analysis, as outlined by Rohrer (2018). Therefore, the current study seeks to find out whether the following hypotheses can be proven or rejected:

1. There is no significant correlation between the instructional management of a teacher in an English language classroom and the quality of instruction as perceived by his/her students.

2. There is no significant correlation between the instructional management skills of a teacher in an English language classroom and the achievements of his/her students.

\section{METHOD}

This study used quantitative research methods, where the data was in the form of numbers, and they were analyzed using statistical methods. It was an observational study in which no variable was controlled.

\section{Participants, Research Instruments and Data Collection}

This research used three types of data, viz: teachers' instructional management skills, students' achievement, and students' perception of teachers' quality of instruction. The data for the teachers' instructional management skills was collected from 26 (Ed: Note I have changed this to 26 to be consistent with what follows below) teachers of English using a questionnaire taken from Martin and Sass (2010). This questionnaire had 12 items, each with a six-point Likert scale, viz: strongly agree (6), agree (5), slightly agree (4), slightly disagree (3), disagree (2), strongly disagree (1). This questionnaire has previously been validated by Sass, Lopes, Oliveira, and Martin (2016), and they found that this "scale provided reasonable evidence of factorial validity and internal consistency and reliability". Unal and Unal (2012), also reported using this questionnaire, and they achieved an internal consistency of 0.75 . 
The data for the achievements of the students was obtained by giving a questionnaire to each of the 509 students who had been taught by the 26 teachers who were selected to complete a questionnaire for this study. For each of these 26 teachers, an average of 19.6 students was assessed. The English language test used for this research was a sample Preliminary English Test (PET) provided by the Cambridge English Language Assessment organisation. This test is designed for students with B1 level of English proficiency, which is the highest targeted level for senior high school students. It has three sections, viz: reading, writing, and speaking. For this study, only the reading section, consisting of 35 questions was used, primarily to save time. In addition, many research studies have also statistically shown that reading skills invariably correlate with the other language skills (Matthews, 2018; Mehrpour \& Rahimi, 2010).

Finally, a questionnaire was distributed to students to assess the quality of instruction given by their teacher based on Voss et al. (2011). This questionnaire asked about various qualities or aspects of instruction such as cognitive activation, pace of instruction, classroom management, social relationship with students, and awareness of any comprehension problems the students had. This questionnaire had 22 statements with a 4-level Likert rating scale. Although the original questionnaire was designed to rate quality of instruction in mathematics, it is not less applicable for students to rate the quality of teaching instruction for learning English (EFL) because the instructional components assessed are not subject-specific. This questionnaire has a satisfactory reliability level (0.70) as reported by Lüdtke, Trautwein, Kunter, and Baumert (2006). The statements in the questionnaire were translated into the student's L1 viz: From English to Indonesian (L1). The English version of the questionnaire is attached as an Appendix. During the analysis, the perceptions of male and female students were analyzed separately to provide the possibility of comparison.

\section{Analysis of Data}

Since the data was obtained by using questionnaires, the data had to be analyzed as categorical data. Before any statistical analysis was conducted, the teacher's instructional management skills and the students' perception of their teachers' pedagogical competence were summed up for each teacher and converted into original scales by using the following formula:

$$
\text { Interval }=\frac{\text { highest-lowest average score }}{\text { number of classes }}
$$

The number of classes was matched to the number of options in the questionnaire, i.e. six scales for the instructional management skills and four scales for the student's perceptions. Quantitative data from the English proficiency test was also transformed into categorical data using the formula above.

The correlation between self-reported instructional management skills and the quality of instruction as perceived by the students was calculated using Spearman's rank correlation method because the data was also categorical data. For a detailed analysis, the data was also separated based on how familiar the students were with the teachers, 
and this was based on the number of years that they had been taught by each specific teacher.

In this study, the analyses were performed by using the "R" statistical package, which is an open source application for basic and advanced level statistical analyses. This statistical tool was used because it is flexible, and programming codes can be used for faster, more customizable analysis procedures.

\section{FINDINGS}

\section{Instructional Management Skills (IM) and Achievements of Students (AS)}

The interval for the teacher's reported instructional management skills and the students' score ranged from 1 to 6 . Therefore, the correlation was calculated based on the converted data for the students' achievements. The result of this analysis is presented in Table 1 .

Table 1

Correlation between Instructional Management Skills and Students' Achievement

\begin{tabular}{llll}
\hline Correlation & S & rho & p-value \\
\hline IM and SA & 2808.7 & 0.03977281 & 0.847 \\
\hline
\end{tabular}

Table 1 shows that the correlation between the two variables was $4 \%$ in the positive direction, but the evidence was not significant, with a significance level $(\alpha)$ of 0.847 . Therefore, there is no statistical evidence that the skills in Instructional Management of a teacher correlate with the Achievements of her/his Students.

\section{Instructional Management Skills (IM) and Perceptions of Students (PS)}

For teacher-reported Instructional Management, the scale ranged from 1 to 6, while the Perceptions of the Students of the quality of instruction demonstrated by their teacher ranged from 1 to 4 . The Perceptions of the Students was broken down into each of the components of quality of instruction, and the correlation was calculated for each component, i.e. Classroom Management (CM), Pace of Instruction (POI), Cognitive Activation (CA), Student-Teacher Relationship (STR), and Awareness of Students' Comprehension Problems (ASCP). The results are presented in Table 2, which follows:

Table 2

Correlation between Instructional Management Skills and Students' Perceptions

\begin{tabular}{llll}
\hline Correlation & S & rho & p-value \\
\hline IM and CM & 4060.3 & 0.09669 & 0.6112 \\
IM and POI & 5142.4 & -0.14403 & 0.4476 \\
IM and CA & 3354.2 & 0.25379 & 0.1760 \\
IM and STR & 4155.9 & 0.07543 & 0.6920 \\
IM and ASCP & 4149.7 & 0.07681 & 0.6866 \\
IM and all components & 3869.5 & 0.13916 & 0.4633 \\
\hline
\end{tabular}

Table 2, above, shows that the Instructional Management skills of the teachers did not correlate, significantly, with any components of quality of instruction as perceived by 
their students. Although some components seem slightly correlated to the Instructional Management of the teachers, these correlations were not significant at 0.1 or 0.05 .

\section{Instructional Management skills and Perceptions of Male vs Female Students}

Gender is one of the determining factors which differentiate between learning by students and their perceptions. To find out whether this applies in our study, we used a Chi-Square Test for the male and female students' perception of teachers' instructional quality, and the results of this are presented in the table that follows.

Table 3

Chi-Square Tests of Perceptions by Male and Female Students

\begin{tabular}{|c|c|c|c|c|c|}
\hline Components of instructional quality & $\begin{array}{l}\text { means } \\
\mathrm{M}\end{array}$ & $\mathrm{F}$ & $\mathrm{X}$-squared & df & p-value \\
\hline Classroom management & 2.536 & 3.103 & 10.566 & 9 & 0.3066 \\
\hline Pace of instruction & 2.286 & 2.690 & 10.996 & 9 & 0.2760 \\
\hline Cognitive activation & 2.821 & 2.483 & 11.314 & 9 & 0.2548 \\
\hline Student-teacher relationships & 1.964 & 2.000 & 27.225 & 9 & 0.0001 \\
\hline $\begin{array}{l}\text { Awareness of comprehension problems of } \\
\text { students }\end{array}$ & 2.250 & 2.034 & 18.407 & 9 & 0.0307 \\
\hline Total & 2.429 & 2.207 & 24.568 & 9 & 0.0035 \\
\hline
\end{tabular}

Table 3 shows that male and female students perceived their teachers' classroom management, pace of instruction, and cognitive activation differently $(\mathrm{p}>0.05)$, however no evidence of differences were found for student-teacher relationships and awareness of student comprehension problems, nor for the combined data total ( $\mathrm{p}<$ $0.05)$. In most cases, female students had a more positive perspective of their teachers' instructional quality. Therefore, we analyzed the correlation between the teacher's selfreported instructional management skills and their pedagogical competence in the form of instructional quality perceived by their male and female students separately. The results of this analysis are summarized in Table 4, which follows:

Table 4

Correlation between Instructional Management Skills and Students' Perception based on Gender Differences

\begin{tabular}{lllll}
\hline Correlation & $\mathrm{M} / \mathrm{F}$ & $\mathrm{S}$ & rho & $\mathrm{p}$-value \\
\hline IM and CM & $\mathrm{M}$ & 2777.6 & 0.23986 & 0.2189 \\
& $\mathrm{~F}$ & 3469.1 & 0.14555 & 0.4512 \\
\hline IM and POI & $\mathrm{M}$ & 3944.4 & -0.079481 & 0.6877 \\
& $\mathrm{~F}$ & 3913.0 & 0.03620 & 0.8521 \\
\hline IM and CA & $\mathrm{M}$ & 3873.5 & -0.06008 & 0.7613 \\
& $\mathrm{~F}$ & 3600.9 & 0.11307 & 0.5592 \\
\hline IM and STR & $\mathrm{M}$ & 3383.1 & 0.07412 & 0.7078 \\
& $\mathrm{~F}$ & 3768.7 & 0.07175 & 0.7115 \\
\hline IM and ASCP & $\mathrm{M}$ & 3323.8 & 0.09035 & 0.6475 \\
& $\mathrm{~F}$ & 3667.9 & 0.09658 & 0.6182 \\
\hline IM and all components & $\mathrm{M}$ & 3299.5 & 0.09700 & 0.6234 \\
& $\mathrm{~F}$ & 3756.0 & 0.07486 & 0.6995 \\
\hline
\end{tabular}


When the data was analyzed separately for males and females, as presented in Table 4, the correlations were absent in all peer groups, whether the components of instructional quality were analyzed as a whole or individually ( $p>0.1)$.

\section{Instructional Management Skills and the Perceptions of Students based on Years of Instruction}

We observed that students who were taught by the same teacher for two semesters perceived their instructional quality differently from those who were taught for four semesters (two years) or more. Therefore, we analyzed the data for any correlation with gender and years of instruction (1,2, and 3 years).

Table 5

Correlation between Instructional Management Skills and Perceptions of Students based on Years of Instruction

\begin{tabular}{lllll}
\hline Length of instruction & Correlation & S & rho & p-value \\
\hline 1 year & IM and CM & 2318.0 & 0.10845 & 0.6058 \\
& IM and POI & 3180.0 & -0.22306 & 0.2838 \\
& IM and CA & 1601.3 & 0.38411 & 0.0580 \\
& IM and STR & 1688.7 & 0.35049 & 0.0858 \\
& IM and ASCP & 1899.2 & 0.26954 & 0.1926 \\
& IM and all components & 1673.3 & 0.35643 & 0.0803 \\
\hline 2year & IM and CM & 1178.1 & 0.11418 & 0.6317 \\
& IM and POI & 1446.9 & -0.08790 & 0.7125 \\
& IM and CA & 916.74 & 0.31072 & 0.1824 \\
& IM and STR & 1373.9 & -0.03304 & 0.8900 \\
& IM and ASCP & 1326.1 & 0.00290 & 0.9903 \\
& IM and all components & 1069.4 & 0.19594 & 0.4077 \\
\hline year & IM and CM & 817.08 & -0.00131 & 0.9960 \\
& IM and POI & 803.23 & 0.01564 & 0.9525 \\
& IM and CA & 980.31 & -0.20135 & 0.4384 \\
& IM and STR & 904.11 & -0.10798 & 0.6800 \\
& IM and ASCP & 834.30 & -0.02242 & 0.9319 \\
& IM and all components & 887.59 & -0.08773 & 0.7377 \\
\hline
\end{tabular}

Table 5 shows that only cognitive activation and student-teacher relationship for the students with one-year of instruction $(35 \%-38 \%)$ were correlated to the instructional management skills at a significance level of $\mathrm{p}<0.1$. For more detailed analysis, Tables 6 and 7 present similar analyses for male and female students separately. 
Table 6

Correlation between Instructional Management Skills and the Perceptions of Male Students based on Years of Instruction

\begin{tabular}{lllll}
\hline Length of instruction & Correlation & S & rho & p-value \\
\hline 1 year & IM and CM & 1332.2 & 0.13495 & 0.5597 \\
& IM and POI & 1351.4 & 0.12249 & 0.5968 \\
& IM and CA & 1414.3 & 0.08163 & 0.7250 \\
& IM and STR & 1032.5 & 0.32954 & 0.1446 \\
& IM and ASCP & 945.95 & 0.38574 & 0.0841 \\
& IM and all components & 1009.4 & 0.34451 & 0.1262 \\
\hline 2 year & IM and CM & 364.00 & 0.00000 & 1.0000 \\
& IM and POI & 378.06 & -0.03863 & 0.9003 \\
& IM and CA & 335.27 & 0.07893 & 0.7977 \\
& IM and STR & 405.07 & -0.11283 & 0.7136 \\
& IM and ASCP & 381.60 & -0.04836 & 0.8753 \\
IMear & IM and all components & 392.13 & -0.07726 & 0.8019 \\
\hline IM and CM & 331.50 & -0.15909 & 0.6214 \\
& IM and POI & 265.59 & 0.07136 & 0.8256 \\
IM and CA & 399.08 & -0.39536 & 0.2033 \\
& IM and STR & 460.88 & -0.61146 & 0.0346 \\
& IM and ASCP & 378.64 & -0.32392 & 0.3040 \\
IM and all components & 418.27 & -0.46249 & 0.1300 \\
\hline
\end{tabular}

Table 6 shows that for male students, only awareness of student comprehension problem for the students with one-year instruction (39\%) and student-teacher relations for those with three-year instruction (61\%) were correlated to the instructional management skills at significance level of $\mathrm{p}<0.1$

Table 7

Correlation between Instructional Management Skills and the Perceptions of Female Students based on Years of Instruction

\begin{tabular}{lllll}
\hline Length of instruction & Correlation & S & rho & p-value \\
\hline 1 year & IM and CM & 728.06 & 0.10776 & 0.6806 \\
& IM and POI & 908.92 & -0.11387 & 0.6634 \\
& IM and CA & 450.94 & 0.44737 & 0.0717 \\
& IM and STR & 804.17 & 0.01449 & 0.9560 \\
& IM and ASCP & 719.58 & 0.11816 & 0.6515 \\
& IM and all components & 686.35 & 0.15888 & 0.5425 \\
\hline year & IM and CM & 934.45 & 0.03565 & 0.8883 \\
& IM and POI & 901.51 & 0.06964 & 0.7836 \\
& IM and CA & 793.36 & 0.18125 & 0.4717 \\
& IM and STR & 1006.9 & -0.03907 & 0.8776 \\
& IM and ASCP & 1049.0 & -0.08258 & 0.7446 \\
& IM and all components & 934.45 & 0.03565 & 0.8883 \\
\hline year & IM and CM & 234.64 & 0.17959 & 0.5765 \\
& IM and POI & 269.69 & 0.05703 & 0.8602 \\
& IM and CA & 250.74 & 0.12328 & 0.7027 \\
& IM and STR & 182.78 & 0.36092 & 0.2491 \\
& IM and ASCP & 160.19 & 0.43989 & 0.1524 \\
& IM and all components & 182.19 & 0.36296 & 0.2462 \\
\hline
\end{tabular}

International Journal of Instruction, October $2020 \bullet$ Vol.13, No.4 
Table 7 shows that the perception of cognitive activation of female students, like the males, was significantly correlated to the instructional management skills of their teacher after one-year of instruction (45\%).

Table 8 , which follows, summarizes all the components of pedagogical competence and instructional management skills which could be correlated.

Table 8

Correlation between Instructional Management Skills and Students' Perception

\begin{tabular}{llllll}
$\begin{array}{l}\text { Correlation between teachers' } \\
\text { instructional management skills and: }\end{array}$ & $\mathrm{N}$ & $\mathrm{S}$ & rho & p-value & Applicability \\
\hline Cognitive activation & 25 & 1601.3 & 0.3841 & 0.0580 & M and F of 1 year \\
& 17 & 450.94 & 0.4473 & 0.0718 & F of 1 year \\
Student - teacher relation & 25 & 1688.7 & 0.3505 & 0.0858 & M and F of 1 year \\
& 12 & 460.88 & -0.6115 & 0.0346 & M of 3 years \\
Awareness of std. comp. & 25 & 945.95 & 0.3857 & 0.0842 & M of 1 year \\
All component & 25 & 1673.3 & 0.3564 & 0.0803 & M and F of 1 year \\
\hline
\end{tabular}

To summarize, Table 8 shows that instructional management skills were significantly correlated to the teacher's instructional quality perceived by both male and female students when they were instructed for no longer than one year. Some components of instructional quality, when analyzed separately, were significantly correlated to instructional management skills of the teachers, viz: cognitive activation for one-year instruction for male and female students, student-teacher relationship for both genders with one-year instruction and for males with three-year instruction, and awareness of comprehension problems for male students with one-year instruction. These can be seen better in Figure 1.
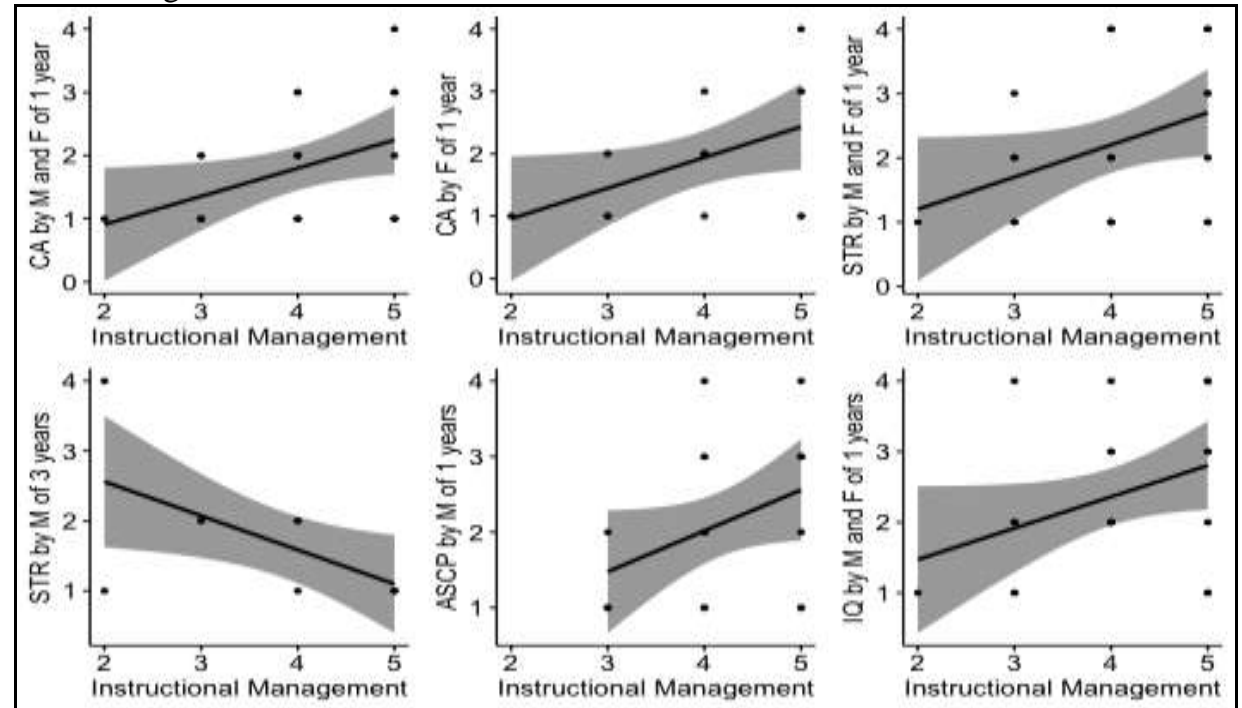

Figure 1

Observed Correlations between Instructional Management and Instructional Quality 


\section{DISCUSSION}

The objective of this study was to find out if there was any correlation between the selfreported instructional management skills of teachers and their quality of instruction as perceived by their students. The study results show that perception of the quality of instruction by the students in this study, as a whole, was not correlated to the selfreported instructional management skills of their teachers. Some significant correlations were however found when the data was analyzed separately based on gender and years of instruction.

For students who received English instruction by the teachers for one year, in general, instructional quality was significantly correlated to the teacher instructional quality perceived by students who received one-year instruction. The individual components of instructional quality which significantly correlated to the instructional management skills were cognitive activation, student-teacher relationships, and awareness of student comprehension problems. For female students, the instructional management skills of their teacher were significantly correlated to quality of instruction when the instruction was only for one year. For male students, the instructional management skills of their teacher were significantly correlated to the quality of instruction when the instruction was for one year or for three years. There was no evidence of correlation between teacher-reported instructional management skills and student-perceived quality of instruction.

The common belief that quality of instruction is significantly correlated with the learning output of students is not supported by any statistical evidence based on the empirical data obtained from the student rating of quality of instruction. This unexpected result can be explained by the fact that learning achievements are mostly determined by the character of students such as their style of learning, aptitude for language, their internal and external motivation and their intelligence (Duff, 2017, p. $380)$. Although quality of instruction has been predicted to impact learning outcomes (Nassaji, 2017, p. 213), such direct correlation was not proven to be significant by the empirical data from this study.

Some correlations were observed between self-reported instructional management skills and some components of quality of instruction as perceived by the students. These results are in line with results from other similar, previous research (Donné et al., 2016; Kettler et al., 2018; Vlčková, Květon, Ježek, Mareš, \& Lojdová, 2019). The results of this study using quantitative empirical data have confirmed that instructional management skills are necessary for student learning, and determine the quality of instruction. Teachers who self-reported having good instructional management skills were rated higher for quality of instruction by their students.

In addition, there was a negative and significant correlation between teacher instructional management skills and quality of instruction as perceived by senior male students. This result suggests that the higher the score that teachers gave themselves for their self-reported instructional management skills, the lower the score they obtained for quality of instruction. As for the correlation with an achievement variable, this negative 
correlation result $(61 \%)$ was also unexpected. However, the items validated by Voss et al. (2011) included in the student rating for this component of quality of instruction can provide some explanation for this unexpected finding.

1) The teacher always addresses students' problems.

2) The teacher always takes time to talk if students want to discuss something with him/her.

3) The teacher does his / her best to respond to students' requests as far as possible.

Most teachers in our study were female, and it is less common for teachers, especially female teachers, in Asian countries like Indonesia, to have lengthy individual discussions with male students, either inside or outside of the classroom (Maulana, Opdenakker, den Brok, \& Bosker, 2011, p. 45). In addition, in countries where students are expected to show great respect to teachers, students don't often make requests to teachers, other than asking questions related to teaching materials. These factors may explain why male students rated the component of student-teacher relationship negatively in this study.

The generalizability of the results from this study is subject to some limitations. First, the direct effect of the instructional management skills of a teacher on the achievements of his/her students was not shown to be significant in this study, but it might provide some mediation between skills in instructional management and the character of students, such as their preferred style of learning, aptitude for language, internal and external motivations, and their intelligence. The absence of such data is a limitation for this study. Another limitation was that this study is observational, and thus any correlation observed does not infer causation. A future experimental study could be conducted to confirm or disprove the results from this study. The most significant weaknesses of this research were that the correlations were mostly observed at a level of significance of 0.1 . This means that there is a $10 \%$ chance that the correlation occurred by chance. This high significance level opens a higher possibility for a type 1 error in the statistical analysis, i.e. rejecting the null hypothesis when it is in fact, actually true. To avoid a type 1 error, Stangor (2011, pp. 152-153) suggests lowering the level of significance. Future research with a larger sample size could also result in better and more confident conclusions. Although the overall sample size in this study was reasonably large, after the data was separated into gender and years of instruction, the sample size was generally below 30 .

\section{CONCLUSION AND PEDAGOGICAL IMPLICATIONS}

This research found that the instructional management skills of the teachers studied did not significantly correlate with instructional quality, but they were significantly correlated with some components of instructional quality. The correlations were mostly positive to correlated components (viz: cognitive activation and awareness of student comprehension problems). While, teacher instructional quality, as perceived by male students who had received three-years of instruction was negatively correlated with teacher-reported instructional management skills. 
The results from this research have some pedagogical implications. Firstly, since instructional management did not correlate with the learning outcomes of their students, teachers should focus on other variables which have more confidently been proven to correlate with them, viz: using methods and activities which have been proven can motivate students and promote better learning by students based on their preferred learning style. According to Lau and Gardner (2019, p. 266), students can achieve more if the teaching method used by their teacher is better matched with their preferred learning style. Furthermore, the negative correlation between instructional management and the teacher-student relationship as perceived by male students with three-year instruction should be seen as a warning to teachers. They should pay more attention to having discussions and coaching their students, both during their classes and also outside the classroom. Although this may not be common in some countries, it can work when approached appropriately.

\section{REFERENCES}

Baumert, J., Kunter, M., Blum, W., Brunner, M., Voss, T., Jordan, A., ... Tsai, Y.-M. (2010). Teachers' mathematical knowledge, cognitive activation in the classroom, and student progress. American Educational Research Journal, 47(1), 133-180. https://doi.org/10.3102/0002831209345157.

Brown, H.D. (2000). Principles of language learning and teaching. New York: Longman

Butler, Y. G., Someya, Y., \& Fukuhara, E. (2014). Online games for young learners' foreign language learning. ELT Journal, 68(3), 265-275. https://doi.org/10.1093/elt/ccu008.

Callahan, C. M. (2006). Assessment in the classroom: The key to good instruction. Waco, TX: Prufrock Press.

Carroll, J. B., \& Sapon, S. M. (1957). Modern languages aptitude test. New York: Psychological Corporation.

Cassidy, S., \& Eachus, P. (2000). Learning style, academic belief systems, self-report student proficiency and academic achievement in higher education. Educational Psychology, 20(3), 307-322. https://doi.org/10.1080/713663740.

Donné, N. Le, Fraser, P., \& Bousquet, G. (2016). Teaching strategies for instructional quality: Insight from the TALIS-PISA link data. OECD Education Working Papers. Paris.

Dörnyei, Z., \& Skehan, P. (2008). Individual differences in second language learning. In The handbook of second language acquisition (pp. 589-630). Oxford, UK: Blackwell Publishing Ltd. https://doi.org/10.1002/9780470756492.ch18.

Duff, P. A. (2017). Social dimensions and differences in instructed SLA. In S. Loewen, \& M. Sato (Eds.), The Routledge Handbook of Instructed Second Language Acquisition, (pp.379-395). New 
https://doi.org/10.4324/9781315676968.

Epstein, S. (1973). The self-concept revisited: Or a theory of a theory. American Psychologist, 28(5), 404-416. https://doi.org/10.1037/h0034679.

Ghofur, A., Rupawandi B. R., N., \& Ahmad, A. K. (2017). Instructional management strategy: A multi-sites study on science teaching for Islamic school. Journal of Educational Science and Technology, 3(3), 211-217. https://doi.org/10.26858/est.v3i3.4210.

Goe, L., Bell, C., \& Little, O. (2008). Approaches to evaluating teacher effectiveness: A Research synthesis. Washington: National Comprehensive Center for Teacher Quality.

Green, C., \& Tanner, R. (2005). Multiple intelligences and online teacher education. ELT Journal, 59(4), 312-321. https://doi.org/10.1093/elt/cci060.

Grigornko, E. L., Sternberg, R. J., \& Ehrman, M. E. (2000). A theory-based approach to the measurement of foreign language learning ability: The CANAL-F theory and test. The Modern Language Journal, 84(3), 390-405. https://doi.org/10.1111/00267902.00076 .

Grossman, P. (2009). Research on pedagogical approaches in teacher education. In M. Cochran-Smith, \& K. M. Zeichner (Eds.), Studying teacher education: The report of the AERA panel on research and teacher education (pp. 425-476). New Jersey: Lawrence Erlbaum Associates, Inc.

Gunawan, I. (2014). Pengaruh supervisi pengajaran dan kemampuan guru mengelola kelas terhadap motivasi belajar siswa [The influence of teaching supervision and teachers' performance on classroom management on students' learning motivation]. Ilmu Pendidikan Jurnal Kajian Teori dan Praktik Kependidikan, 41(1), 44-52.

Gutierrez, J. C., Holladay, S. D., Arzi, B., Clarkson, C., Larsen, R., \& Srivastava, S. (2019). Improvement of spatial and non-verbal general reasoning abilities in female veterinary medical students over the first 64 weeks of an integrated curriculum. Frontiers in Veterinary Science, 6, 141. https://doi.10.3389/fvets.2019.00141.

Hung, H. T. (2018). Gamifying the flipped classroom using game-based learning materials. ELT Journal, 72(3), 296-308. https://doi.org/10.1093/elt/ccx055.

Kemp, J. (2009). The listening log: Motivating autonomous learning. ELT Journal, 64(4), 385-395. https://doi.org/10.1093/elt/ccp099.

Kettler, R. J., Arnold-Berkovits, I., Reddy Rutgers, L. A., Kurz, A., Dudek, C. M., Hua, A. N., \& Lekwa, A. (2018). Multi-method teacher evaluation for high poverty schools: Observations and self-ratings of instructional and behavioral management. Studies in Educational Evaluation, 59, 224-234. https://doi.org/10.1016/j.stueduc.2018.08.004.

Kolb, A. Y., \& Kolb, D. A. (2005). Learning styles and learning spaces: Enhancing experiential learning in higher education. Academy of Management Learning \& Education, 4(2), 193-212. https://doi.org/10.5465/amle.2005.17268566. 
König, J., Blömeke, S., Paine, L., Schmidt, W. H., \& Hsieh, F. J. (2011). General pedagogical knowledge of future middle school teachers: On the complex ecology of teacher education in the united states, Germany, and Taiwan. Journal of Teacher Education, 62(2), 188-201. https://doi.org/10.1177/0022487110388664.

Kunter, M., \& Voss, T. (2013). The model of instructional quality in COACTIV: A multicriteria analysis. In M. Kunter, J. Baumert, W. Blum, U. Klusmann, S. Krauss, \& M. Neubrand (Eds.), Cognitive activation in the Mathematics classroom and professional competence of teachers: Results from the COACTIV project (pp. 97-124). New York: Springer. https://doi.org/10.1007/978-1-4614-5149-5_6.

Kurdi, S., \& Aziz, A. (2006). Model pembelajaran efektif pendidikan Agama Islam di $S D$ dan MI [Effective teaching model for Islamic Education module at elementary schools]. Bandung: Pustaka Bani Quraisy.

Lau, K., \& Gardner, D. (2019). Disciplinary variations in learning styles and preferences: Implications for the provision of academic English. System, 80, 257-268. doi: 10.1016/j.system.2018.12.010.

Lüdtke, O., Trautwein, U., Kunter, M., \& Baumert, J. (2006). Reliability and agreement of student ratings of the classroom environment: A reanalysis of TIMSS data. Learning Environments Research, 9(3), 215-230. doi: 10.1007/s10984-006-9014-8.

Martin, N. K., \& Sass, D. A. (2010). Construct validation of the behavior and instructional management scale. Teaching and Teacher Education, 26(5), 1124-1135. https://doi.org/10.1016/j.tate.2009.12.001.

Matthews, J. (2018). Vocabulary for listening: Emerging evidence for high and midfrequency vocabulary knowledge. System, 72, 23-36. https://doi.org/10.1016/j.system.2017.10.005.

Maulana, R., Opdenakker, M. C., den Brok, P., \& Bosker, R. (2011). Teacher-student interpersonal relationships in Indonesia: Profiles and importance to student motivation. Asia Pacific Journal of Education, 31(1), 33-49. https://doi.org/10.1080/02188791.2011.544061.

McDonough, S. (2007). Motivation in ELT. ELT Journal, 61(4), 369-371. https://doi.org/10.1093/elt/ccm056.

McLeod, J., Fisher, J., \& Hoover, G. (2003). The key elements of classroom management: managing time and space, student behavior, and instructional strategies. Alexandria: Association for Supervision and Curriculum Development.

Meara, P. (2005). LLAMA language aptitude tests: The manual. Lognostics: University of Swansea. Retrieved from www. lognostics.co.uk/tools/llama.

Mehrpour, S., \& Rahimi, M. (2010). The impact of general and specific vocabulary knowledge on reading and listening comprehension: A case of Iranian EFL learners. System, 38(2), 292-300. https://doi.org/https://doi.org/10.1016/j.system.2010.01.004. 
Mercer, S. (2012). Dispelling the myth of the natural-born linguist. ELT Journal, 66(1), 22-29. https://doi.org/10.1093/elt/ccr022.

Mulyasa, E. (2002). Manajemen berbasis sekolah: Konsep, strategi, dan implementasi [School-based management: Concepts, strategy, and implementation]. Bandung: PT Remaja Rosda Karya.

Nassaji, H. (2017). Grammar acquisition. In S. Loewen, \& M. Sato (Eds.), The Routledge handbook of instructed second language acquisition (pp. 205-223). New York: Routledge.

Pritchard, A. (2009). Ways of learning: Learning theories and learning styles in the classroom. London: David Fulton.

Puspitasari, A., Anugerahwati, M., \& Rachmajanti, S. (2016). Teachers pedagogical and professional competences in CLIL-based primary schools in Indonesian context. In International conference on education (pp. 105-115). Malang: Universitas Negeri Malang. https://doi.org/10.1007/s00199-011-0648-0.

Raganas, N. S., \& Collado, L. S. (2015). Professional attributes: Implications to instructional management skills of teachers. Annals of Studies in Science and Humanities, 1(1), 84-94.

Rahman, M. H. (2014). Professional competence, pedagogical competence and the performance of junior high school of science teachers. Journal of Education and Practice, 5(9), 75-80.

Reid, J. M. (1995). Learning styles in the ESL/EFL classroom. Boston, MA: Heinle and Heinle.

Rogers, V., Meara, P., Barnett-Legh, T., Curry, C., \& Davie, E. (2017). Examining the LLAMA aptitude tests. Journal of the European Second Language Association, 1(1), 49-60. https://doi.org/10.22599/jesla.24.

Rohrer, J. M. (2018). Thinking clearly about correlations and causation: Graphical causal models for observational data. Advances in Methods and Practices in Psychological Science, 1(1), 27-42. doi: 10.1177/2515245917745629.

Saraswaty, D. R. (2018). Learners' difficulties \& strategies in listening comprehension. English Community Journal, 2(1), 139-152.

Sass, D. A., Lopes, J., Oliveira, C., \& Martin, N. K. (2016). An evaluation of the behavior and instructional management scale's psychometric properties using Portuguese teachers. Teaching and Teacher Education, 55, 279-290. https://doi.org/10.1016/j.tate.2016.01.020.

Skehan, P. (2012). Language Aptitude. In S. M. Gass \& A. Mackey (Eds.), The Routledge handbook of second language acquisition (pp. 381-395). Oxon: Routledge Taylor \& Francis Group.

Stangor, C. (2011). Research methods for the behavioral sciences. Belmont: 
Wadsworth, Cengage Learning.

Unal, Z., \& Unal, A. (2012). The impact of years of teaching experience on the classroom management approaches of elementary school teachers. International Journal of Instruction, 5(2), 41-53.

Vlčková, K., Květon, P., Ježek, S., Mareš, J., \& Lojdová, K. (2019). Adaptation of the behavior and instructional management scale to Czech classroom conditions. Studia Paedagogica, 24(1), 135-155. https://doi.org/10.5817/SP2019-1-6.

Voss, T., \& Kunter, M. (2013). Teachers' general pedagogical/psychological knowledge. In cognitive activation in the mathematics classroom and professional competence of teachers (pp. 207-227). Boston, MA: Springer US. https://doi.org/10.1007/978-1-4614-5149-5_10.

Voss, T., Kunter, M., \& Baumert, J. (2011). Assessing teacher candidates' general pedagogical/psychological knowledge: Test construction and validation. Journal of Educational Psychology, 103(4), 952-969. https://doi.org/10.1037/a0025125.

Waddington, J. (2018). Teacher understanding and implementation of motivational strategies in ELT. ELT Journal, 72(2), 162-174. https://doi.org/10.1093/elt/ccx044.

Wen, Z. (2012). Foreign language aptitude. ELT Journal, 66(2), 233-235. https://doi.org/10.1093/elt/ccr068.

Wilson, S., \& Youngs, P. (2009). Research on accountability processes in teacher education. In M. Cochran-Smith \& K. M. Zeichner (Eds.), Studying teacher education: The report of the AERA panel on research and teacher education (pp. 591-644). New Jersey: Lawrence Erlbaum Associates, Inc.

Zafar, S., \& Meenakshi, K. (2012). Individual learner differences and second language acquisition: A review. Journal of Language Teaching and Research, 3(4), 639-646. https://doi.org/10.4304/jltr.3.4.639-646. 